\title{
微粘分混入率がRCD用コンクリートの諸特性に 及ぼす影響
}

本研究は, RCD 用コンクリートに石灰石粉, 珪石粉, 堆砂粉などの混入率を変化し た場合に, VC 值, 圧縮強度, 密度などが如何なる特性を示すか明らかにするために行っ た。 その結果, それぞれの石粉により異なるが, 最適混入率の場合にVC 值は適切で, 強度，密度が増大することが明らかとなった。

Key Words : RCD concrete, dam construction, fine powder

\section{1.はじめに}

近年，日本で開発された RCD（Roller Compacted Dam-Concrete）工法は，わが国の重力式コンクリート ダム施工の主流となっている.すでに日本で RCD 工法 によって建設されたダムは 15 箇所, 建設中のダムも 16 箇所と多く, 今後, 益々, 普及するものと考えられる. また，アメリカなど世界の多数の諸国で施工された RCC (Roller Compacted Concrete) ダムは 92 箇所之 多くなっている．施工の多い国はアメリカ，中国，才ー ストラリア，スペイン，南アフリカ，フランス，モロッ コ，アルゼンチンなどである(1,21,4) 6).

RCC工法によって，初期にアメリカで施工された Willo Creek ダム, Galesville ダムなどは, 結合材料 (セ メント+フライアッシュ) の少ないものであった.この ため堤体から漏水があり, 強度も小さいものであった. このような欠点を補うため, 最近, 施工されるダムは結 合材料が多いダムが増加している ${ }^{3,7), 81}$.

これに対してRCD 工法では結合材料が $120 〜 130$ $\mathrm{kg} / \mathrm{m}^{3}$ で，この内フライアッシュは結合材料の 20 - 30\% である，RCD用コンクリートは温度上昇を少なくする 必要上から結合材料を少なくしているので，骨材分離が 生じないよう注意深い施工が必要である. 特に砕砂の形 状の悪い場合には骨材分離が生じ易く, 施工性の悪いコ ンクリートになり易い ${ }^{1), 21}$.

一方, RCD 用コンクリートは従来のコンクリートと 異なり, 細骨材の $0.15 \mathrm{~mm}$ 以下の微粒分がある程度の 量が含有されているほうが施工し易く, 骨材の分離も少 ないことが明らかになっている。このようなことから， 一部のダムでは石粉を混入しているダムもある. また,

*正会員 工修 愛知県河川工事事務所

( ₹459 名古屋市西区稲生町杁先 2200-29)

**正会員 工博 名城大学教授 理工学部土木工学科
石粉を混入した RCD 用コンクリートの試験も一部で行

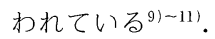

このようなことから, 本研究では, 珪石粉, 石灰石粉, 堆砂粉などの材料を混入することにより, RCD 用コン クリートの強度の向上と施工性を良好にする目的で実施 したものである．実験方法は基本となるセメント量を変 化し, それぞれについて珪石粉, 石灰石粉, 堆砂粉の混 入量を変化した場合, VC 值, 強度, 密度などの変化か ら RCD 用コンクリートの特性を明らかにした。また， 材粡により如何なる変化をするかについても明らかにし た.

この他, RCD 用コンクリートのフライアッシュを珪 石粉, 堆砂粉と置換え率を変化し, VC 値, 圧縮強度, 密度なよ゙の変化から，これらの特性も明らかにした。

一方, 実験を行うに当り，コンクリートの練混ぜ時間， テストピースの締固め時間については明確になっていな い. そこで, コンクリートの練混ぜ時間と強度, テスト ピースの締固め時間と強度の関係について実験を行い, 適切なコンクリート練混ぜ時間, テストピース締固め時 間を決定し，これを基に一連の実験を行った.

\section{2. 微粒分の必要性}

$\mathrm{RCD}$ 工法では, RCD 用コンクリートの配合特性を $\alpha$, $\beta$ 值で示している. $\alpha$ の値はペースト容積と細骨材の空 隙容積との比を示すもので, $\beta$ の值はモルタルの容積と 粗骨材の空陌容積との比を示すものである.ただし,ペー スト, モルタルの容積に空気の容積を含めないものとし ている.したがって $\alpha$ の值が 1 より大きい場合には, 細骨材の空陌を満たす量よりも余分のペーストであるこ とを示している. 同様に $\beta$ の値が 1 より大きい分だけ 余分のモルタルが用いられていることを示すものであ る.この余分のペースト, または, モルタルは全骨材の 表面を覆うためにある程度の量が必要である.この余分 
表一1 RCD 用コンクリートとダム用コンクリートの配合特性

\begin{tabular}{|c|c|c|c|c|c|c|c|c|c|c|}
\hline 種別 & ダム名 & $\begin{array}{l}\text { 最大寸法 } \\
\text { Gmax mm }\end{array}$ & $\begin{array}{c}\mathrm{V} \text { C值 } \\
\mathrm{sec}\end{array}$ & \multicolumn{2}{|c|}{ フライアッシュ比 } & $\begin{array}{c}\text { 細骨材率 } \\
\text { S/a \% }\end{array}$ & $\begin{array}{r}\text { 単位水量 } \\
\mathrm{W} \mathrm{kg} / \mathrm{m}^{3} \\
\end{array}$ & $\begin{array}{l}\text { セメント } \\
\mathrm{C}+\mathrm{F} \mathrm{kg} / \mathrm{m}^{3}\end{array}$ & $\alpha$ & $\beta$ \\
\hline $\mathrm{R}$ & A ダム & 80 & 15 & 20 & & 32 & 102 & 120 & 1.18 & 1.30 \\
\hline & B ダム & 80 & 20 & 20 & & 33 & 103 & 120 & 1.17 & 1.32 \\
\hline $\mathrm{C}$ & C ダム & 80 & 20 & 20 & & 31 & 100 & 120 & 1.08 & 1.22 \\
\hline & D ダム & 80 & 40 & 20 & & 32 & 92 & 120 & 1.20 & 1.43 \\
\hline $\mathrm{D}$ & Eダム & 80 & 20 & 20 & & 30 & 103 & 120 & 1.11 & 1.26 \\
\hline & Fダム & 80 & 20 & 20 & & 30 & 105 & 120 & 1.05 & 1.22 \\
\hline ダ & Gダム & 80 & 15 & 30 & & 34 & 105 & 130 & 1.23 & 1.52 \\
\hline & H ダム & 80 & 20 & 30 & & 32 & 100 & 130 & 1.14 & 1.58 \\
\hline 么 & I ダム & 150 & 20 & 30 & & 29 & 95 & 130 & 1.08 & 1.21 \\
\hline 従ダ & 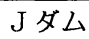 & 150 & - & 0 & & 25 & 115 & 170 & 1.27 & 1.27 \\
\hline 来ム & Kダム & 150 & 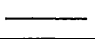 & 0 & & 27 & 110 & 180 & 1.24 & 1.32 \\
\hline
\end{tabular}

の量が少ない場合には骨材分離が生じ，施工の困難なコ ンクリートになっている1,21,91.

表一1 は RCD 用コンクリートと従来のダム用コンク リートの配合特性を示したものであり， $\alpha, \beta$ は次式に より求めたものである.

$\alpha=\frac{\text { コンクリート } 1 \mathrm{~m}^{3} \text { 中のペースト容積 }}{\text { コンクリート } 1 \mathrm{~m}^{3} \text { に用いる細骨材の空隙容積 }}$ $=\frac{W+C / \rho_{C}+F / \rho_{F}}{\left(1000 / W_{s o}-1 / \rho_{S}\right) \cdot S}$

$\beta=\frac{\text { コンクリート } 1 \mathrm{~m}^{3} \text { 中のモルタル容積 }}{\text { コンクリート } 1 \mathrm{~m}^{3} \text { に用いる粗骨材の空隙容積 }}$ $=\frac{W+C / \rho_{C}+F / \rho_{F}+S / \rho_{S}}{\left(1000 / W_{G O}-1 / \rho_{G}\right) \cdot G}$

ここに, $\rho_{C}, \rho_{F}, \rho_{S}, \rho_{G}:$ セメント, フライアッシュ, 細骨材, 粗骨材の比重

$W_{S O}$ ：振動台で締固めた細骨材の単位容積重量

$W_{G O}$ : 振動台で締固めた粗骨材の単位容積重量

$W, C, F, S, G$ : 各材料の単位容積重量

表一1 から, RCD 用コンクリートの $\alpha$ 值は, 従来の ダム用コンクリートの $\alpha$ 值より小さな值となっている. これは，結合材料を少なくしているためで， $\alpha$ 値の小さ い場合には注意深く薄層敷均しを行わないと骨材の分離 が生じ，施工性の悪いコンクリートとなっている．D ダムは河床骨材を使用しているので，結合材料が 120 $\mathrm{kg} / \mathrm{m}^{3}$ にもかかわらず，他のダムより $\alpha$ 值が大きく, 施工が容易なコンクリートであった。また， G，H ダム は扁平な砕石の骨材のため, 結合材料を多くして $\alpha$ 值 をわずかに大きくしているが，施工性の悪いコンクリー トであった。このように， $\alpha$ 值の小さいコンクリートは 施工性の悪いコンクリートとなっている(1,91,111,12). そこ で, 発熱の生じないフライアッシュ, 石灰石粉, 珪石粉, 堆砂粉などの微粒分を混入することにより，圧縮強度の 増大と施工性を良好にすることが重要である。
表一2 RCC, RCD 用コンクリートの結合材料

\begin{tabular}{|l|l|r|r|r|r|}
\hline \multicolumn{1}{|c|}{ ダ 名 } & 国 名 & C & \multicolumn{1}{c|}{ F } & C + F & 着手年 \\
\hline Willow Creek & USA & 47 & 19 & 66 & 1982 \\
Monksville & USA & 62 & 0 & 62 & 1986 \\
Upper Stillwater & USA & 77 & 170 & 247 & 1987 \\
Los Morales & Spain & 81 & 140 & 221 & 1987 \\
Knellpoort & S.Africa & 61 & 142 & 203 & 1988 \\
Stagecoach & USA & 71 & 77 & 148 & 1988 \\
岩灘 & China & 55 & 95 & 150 & 1989 \\
水口 & China & 65 & 95 & 160 & 1990 \\
\hline 島地川 & Japan & 84 & 36 & 120 & 1980 \\
玉川 & Japan & 91 & 39 & 130 & 1987 \\
\hline
\end{tabular}

一方， RCC 工法では，初期に施工したダムは結合材 料が非常に少ないため, 強度が小さく漏水もあり施工性 の悪いコンクリートであった. その後, この対策として 多くの施工経験を基に, フライアッシュを多量に混入し, 改善を図るダムが増加している．これらの変化を表して いる代表的なダムについて示すと表一2 となる.

初期の RCC 用コンクリートの結合材料は，表一2に 示すように $62 \sim 66 \mathrm{~kg} / \mathrm{m}^{3}$ と非常に小さく品質が良好で なかった。このようなことから，その後の施工では結合 材料を増加し， $148 \sim 247 \mathrm{~kg} / \mathrm{m}^{3}$ も使用するダムもあり， 最近のダムはこのように八イペーストの RCC ダムが多 くなってきている。このような状況について，1989年 までに施工されたダムを図一1に示した。1991年に施工 された RCC ダムは 17 箇所であるが，このうち，八イ ペーストのダムは 11 箇所である. また， 1992 年までに 施工された RCC ダムは 92 箇所であるが，八イペース トのダムは，このうち $55 \%$ と急激に増加している。こ の原因は，八イペーストのため骨材分離が少なく，強度 が大きく，水密性の良好なコンクリート亡なり，品質が 非常に向上したためである，また，強度の必要な高いダ 


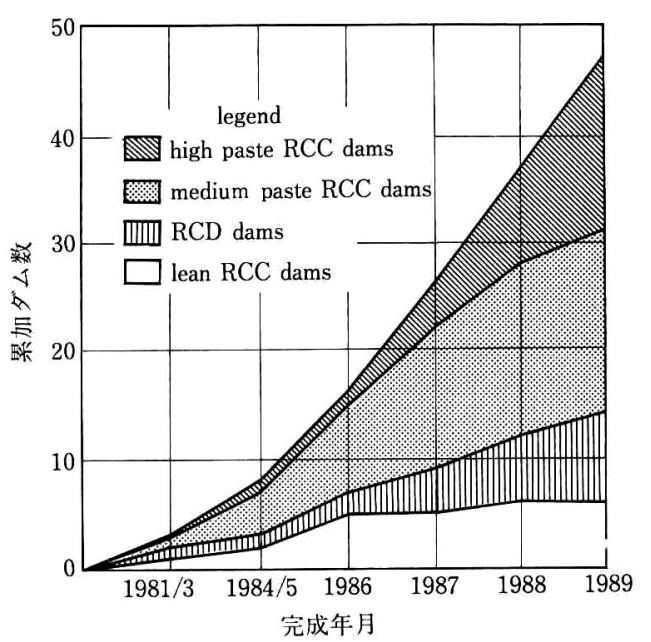

図一1 各タイプの累加ダム数

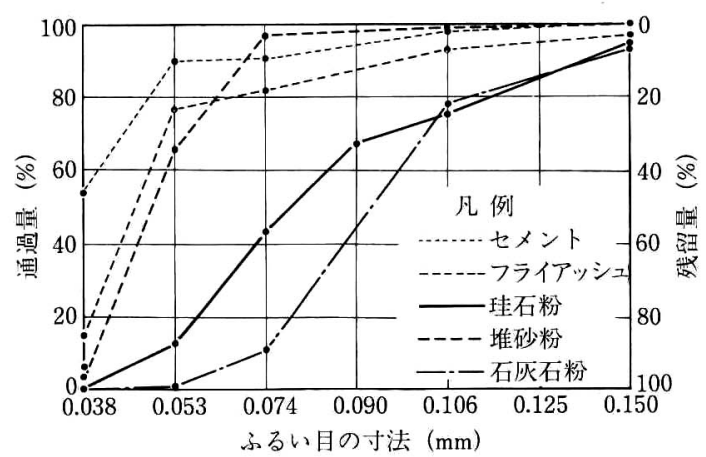

図-2 石灰石粉, 珪石粉, 堆砂粉の粒度分布

表一3 微粒分の物理的性質

\begin{tabular}{|c|c|c|c|c|}
\hline a & a & 此 & 重 & ○. 074 吅の通迥 \\
\hline$t x \nu$ & $r$ & & 22 & $92.0 \%$ \\
\hline フライアッシ & & 2. & 30 & $82.0 \%$ \\
\hline 生 石 & 粠 & 2. & 65 & 43. $0 \%$ \\
\hline 埋 秒 & 访 & 2. & 71 & $97.0 \%$ \\
\hline 石质石 & 糟 & 2. & 82 & 12. $0 \%$ \\
\hline
\end{tabular}

ムの建設が多くなってきていることにもよるものと考え られる21.71,8).

以上のようなことから, RCD 用コンクリートでも微 粒分の多いコンクリートの研究開発が必要である.

\section{3. 実 験 概 要}

\section{（1）使用材料}

使用材料は中庸熱セメント，フライアッシュと微粒分 として石灰石粉, 珪石粉, 堆砂粉を使用した. 混和剂は ポゾリス No. 8 在使用した. 骨材は花崗岩の砕砂, 砕石

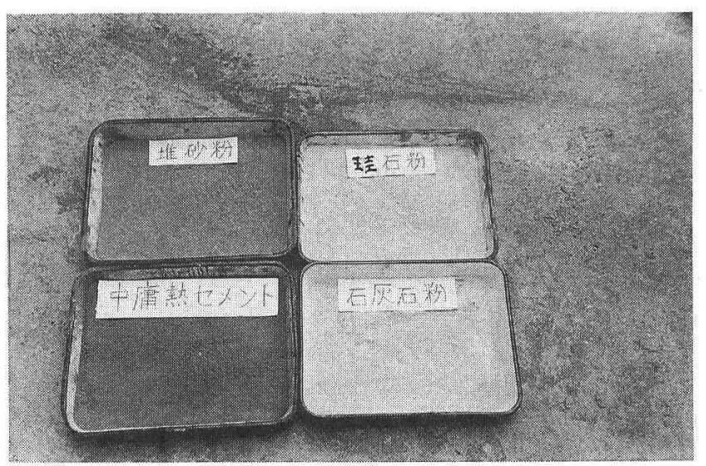

写真一1 石灰石粉, 珪石粉, 堆砂粉

表一4 骨材の物理的性倎

\begin{tabular}{|c|c|c|}
\hline & 比 重 & 粗粒率 \\
\hline 細 骨 材 & 2. 62 & 2. 87 \\
\hline 粗 骨 材 & 2. 60 & 8. 00 \\
\hline
\end{tabular}

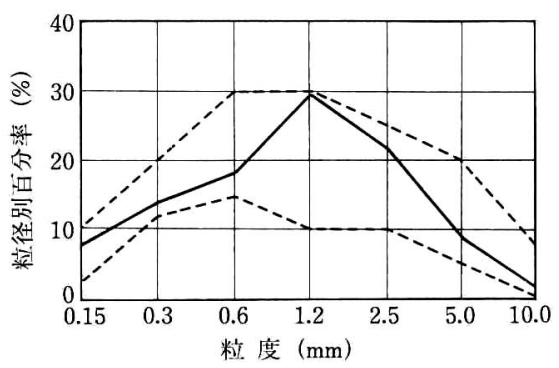

図一3 細骨材粒度 粒度 $(\mathrm{mm})$

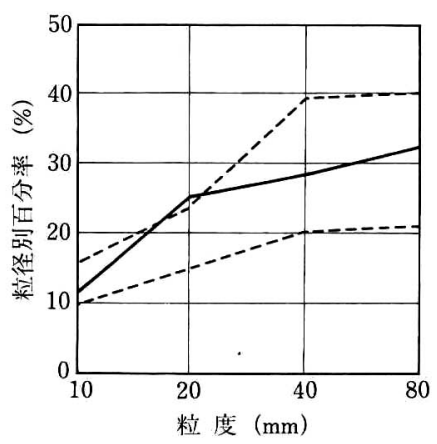

図一4 粗骨材粒度 粒度 $(\mathrm{mm})$

を用いた。

セメント, フライアッシュ, 石灰石粉, 珪石粉, 堆砂 粉の粒度分布は図一2のようで, 堆砂粉は, フライアッ シュに近い粒度であり, 石灰石粉, 珪石粉はある程度大 きい粒度である。

これらの物理的性質は表一 3 に示すとおりである.

また, セメント, 石灭石粉, 珪石粉, 堆砂粉は写真一 1 の上うであり，外観からは同様の粒度に見える。

堆砂粉は美和ダム (中部地方建設局) の堆砂であって 
表一5 VC 試験機の性能

\begin{tabular}{|c|c|}
\hline 称 & 性 \\
\hline 変 速 & 無段変速 $700 \sim 6,000 \mathrm{c} \mathrm{p} \mathrm{m}$ \\
\hline 電 源 & 3 相 $200 \mathrm{~V}$ \\
\hline 出 力 & $\mathrm{AC}\left(\begin{array}{lll}6 & 0 & \mathrm{c}\end{array} / \mathrm{s}\right)$ \\
\hline 振 動 数 & $600 \sim 6,000 \mathrm{c} \mathrm{p} \mathrm{m}$ \\
\hline 振 幅 & 1. $0 \mathrm{~mm}, 0.8 \mathrm{~mm}, 0.3 \mathrm{~mm}$ \\
\hline 自 記 式 & $\begin{array}{l}\text { シンクロナスモータ式 } \\
\text { 回転数 ; } 2 \text { v p m、電圧 ; A V } 200 \mathrm{~V}\end{array}$ \\
\hline $\begin{array}{l}\text { モールド } \\
\text { 寸 法 }\end{array}$ & $\begin{array}{l}\text { 内径；24 c m、48 c m } \\
\text { 高さ ; } 20 \mathrm{c} \mathrm{m} 、 40 \mathrm{c} \mathrm{m}\end{array}$ \\
\hline 形 状 & $60 \mathrm{~cm} \times 60 \mathrm{~cm}$ \\
\hline
\end{tabular}

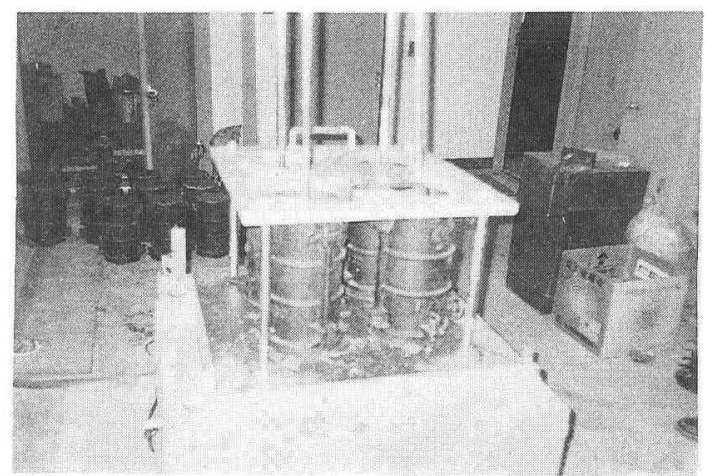

写真一2 VC 試験機によるテストピースの作成

約 1000 万 $\mathrm{m}^{3}$ の堆砂量の内, 約 $80 \%$ が微粒分である. この上うに多量の堆砂粉が RCD 用コンクリートの材料 として利用が可能となれば非常に経済的である.

次に, 砕砂, 砕石の物理的性質は表一4のようであり, 粒度分布は図一 $3 ， 4$ の上うである.この図から明らか なように，一部分が上木学会ダムコンクリート標準示方 書による粗骨材の粒度の標準範囲外となっているが, 全 体的にはほぼ良好である。

\section{(2) 使用機器}

使用機器の主なものはVC (Vibrating Compaction) 試験機で，他の機器は一般的なコンクリート奏験に用い るものである.実験に用いた VC 試験機は, 振幅 $1 \mathrm{~mm}$, 振動数 $3000 \mathrm{cpm}$, 振動時間制御付である.

この VC 試験機の性能を示すと表一5のようである.

\section{（3）実験方法}

$\mathrm{RCD}$ 用コンクリートの練混ぜは, 可傾型動力ミキサ により練混ぜ時間は次に示す実験結果から 4 分間とし た.

VC 値の測定は测定用モールド寸法が内径 $24 \mathrm{~cm}$, 高 さ $20 \mathrm{~cm}$, 載荷重用おもり $20 \mathrm{~kg}$ を載荷した標準試験と した， RCD 用コンクリートは $40 \mathrm{~mm}$ ふるいでウェット スクリーニングして測定した。

圧縮強度試験のためのテストピースの作成は, VC試
表一6 RCD 用コンクリート配合

\begin{tabular}{|c|c|c|c|c|}
\hline \multicolumn{2}{|c|}{ 粗骨材の最大寸法 } & $(\mathrm{mm})$ & 80 & 80 \\
\hline \multicolumn{2}{|c|}{ 空気量 } & $(\%)$ & 1. 5 & 1. 5 \\
\hline \multicolumn{2}{|c|}{ 水セメント比 } & $(\%)$ & 87.5 & 87.5 \\
\hline \multicolumn{2}{|c|}{ フライアッシュ比 $\mathrm{F} /(\mathrm{C}+\mathrm{F})$} & $(\%)$ & 30 & 30 \\
\hline 紐骨材率 & $\mathrm{S} / \mathrm{a}$ & $(\%)$ & 34 & 34 \\
\hline \multirow{6}{*}{$\begin{array}{r}\text { 単位重量 } \\
\left(\mathrm{kg} / \mathrm{m}^{3}\right)\end{array}$} & 水 & $\mathrm{W}$ & 105 & 105 \\
\hline & セメント & $\mathrm{C}$ & 84 & 84 \\
\hline & フライアッシュ & F & 36 & 12 \\
\hline & 堆砂粉 & S S & 0 & 24 \\
\hline & 紐骨材 & S & 738 & 738 \\
\hline & 粗骨材 & $\mathrm{G}$ & 1,468 & 1,468 \\
\hline
\end{tabular}

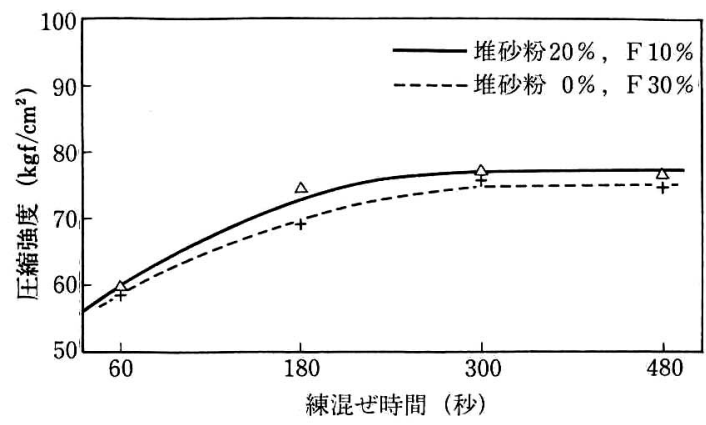

図一 5 練混ぜ時間と圧縮強度の関係

験機の上に直径 $15 \mathrm{~cm}$, 高さ $30 \mathrm{~cm}$ の円柱型枠に RCD 用コンクリートをウェットスクリーニングし，3 層に打 込み各層の締固め時間は次に示す実験結果から全て 20 秒亡し作成した. この作成状況を写真一 2 に示す.

\section{4. 練混ぜ時間, 締固め時間について}

練混ぜ時間は， RCD 用コンクリートの特徴に大きな 影響を与える.しかし，練混ぜ時間に関する実験は行わ れていない，そこで，練混ぜ時間を変化し，これに対す る圧縮強度の関係加ら適切な練混ぜ時間を決定すること にした。

RCD 用コンクリートの配合は表一6に示すように， フライアッジュをセメントの $30 \%$ 混入したケースと, このフライアッシュを $10 \%$, 堆砂粉を $20 \%$ 混入した ケースについて夷験を行った．王縮強度試験の材㱓は 28 日とした。

以上の配合により練混ぜ時間を 60 秒, 180 秒, 300 秒, 480 秒としてテストピースを作成し，圧縮強度試験を 行った. その結果を図示すると図一5のようになる.こ の図から，堆砂粉をフライアッシュと置換えを行った ケースと, 行わないケースでは, ほぼ同様の傾向を示し ている．また，練混ぜ時問が 240 秒になると強度をほぼ 出しきり，これ以上の練混ぜを行っても強度の伸びがな いことが明らかとなった，そこで本実験では RCD 用コ 


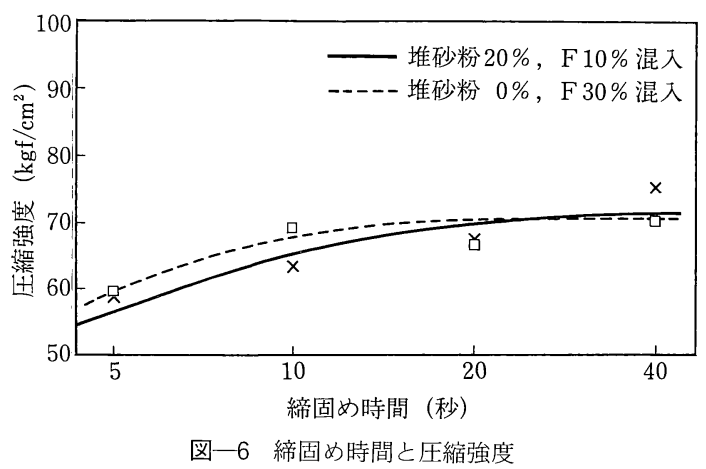

表一7 珪石粉を混入した場合の配合

\begin{tabular}{|c|c|c|c|c|c|c|c|c|}
\hline \multicolumn{3}{|c|}{ 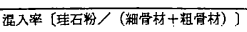 } & (\%) & 0.0 & 3.5 & 7.3 & 11.4 & 15.8 \\
\hline \multicolumn{3}{|c|}{ 粗骨材の最大寸法 } & (nn) & 80 & 80 & 80 & 80 & 80 \\
\hline \multicolumn{3}{|l|}{ 空気量 } & (\%) & 1.5 & 1.5 & 1.5 & 1.5 & 1.5 \\
\hline \multicolumn{2}{|c|}{ 水セメント比 } & $\mathrm{W} /(\mathrm{C}+\mathrm{F})$ & (\%) & 91.7 & 91.7 & 91.7 & 91.7 & 91.7 \\
\hline \multicolumn{3}{|c|}{ フライアッシュ比 F/ $(\mathrm{C}+\mathrm{F})$} & (\%) & 30 & 30 & 30 & 30 & 30 \\
\hline \multicolumn{2}{|c|}{ 緗骨材車 } & $\mathrm{s} / \mathrm{a}$ & (\%) & 34 & 34 & 34 & 34 & 34 \\
\hline \multirow{5}{*}{$\begin{array}{r}\text { 単位重童 } \\
\left(\mathrm{kg} / \mathrm{m}^{\mathrm{s}}\right)\end{array}$} & \multicolumn{2}{|l|}{ 水 } & W & 110 & 110 & 110 & 110 & 110 \\
\hline & \multicolumn{3}{|c|}{ フライアッシュ } & 120 & 120 & 120 & 120 & 120 \\
\hline & \multicolumn{2}{|l|}{ 親骨材 } & $\mathrm{s}$ & 734 . & 660 & 587 & 514 & 440 \\
\hline & \multicolumn{2}{|l|}{ 粗骨材 } & G & 1,457 & 1,457 & 1,457 & 1,457 & 1,457 \\
\hline & \multicolumn{3}{|l|}{ 理石籺 } & 0 & 75 & 150 & 225 & 300 \\
\hline
\end{tabular}

ンクリートの練混ぜ時間を 240 秒と決定し，この時間を 基に実験を行った。

締固め時間についても練混ぜ時間と同様の表一6の配 合としたＶ VC 試験機による締固めは，テストピースを $\mathrm{VC}$ 試験機に乗せ，テストピース内の RCD 用コンク リート上に $5 \mathrm{~kg}$ の載荷を行い，締固め時間を 5 秒，10 秒，20 秒，40秒についてそれぞれ行った. その結果を 図示する亡図一6のようになる。この図から，堆砂粉を フライアッシュに置き換えたケースと，置き換えない ケースではほぼ同様の傾向を示している. また, 締固め 時間が 20 秒になると強度を出しきり，これ以上の締固 めを行っても強度の伸びが少ないことが明らかとなっ た。 そこで, 本実験では圧縮試験用のテストピースの作 成のための締固め時間を 20 秒と決定し，この時間を基 に実験を行った。

\section{5. 微粒分を混入した場合のコンシステンシー と圧縮強度，密度の関係についての考察}

微粒分を混入した実験に先立ち，コンシステンシーを 如何にすべきか明らかにしておく必要がある，そこで， 単位水量を $105,110,120 \mathrm{~kg} / \mathrm{m}^{3}$ の 3 ケースについて実 験を行った.

石灰石粉, 珪石粉, 堆砂粉の中で中間的な粒度分布で ある珪石粉について表一7に示した配合で行った。なお 単位水量 $105,120 \mathrm{~kg} / \mathrm{m}^{3}$ については, わずかに細骨材 量が変る以外は同様である.

以上の結果, 図一7 に示した混入率と VC 值の関係か
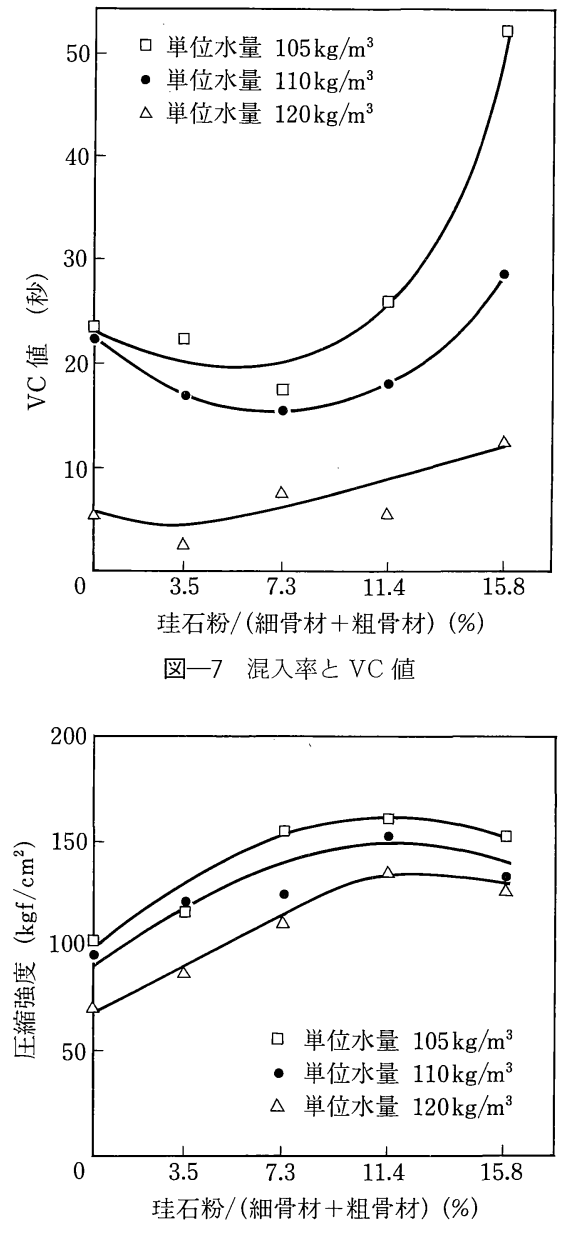

図一8 混入率と圧縮強度

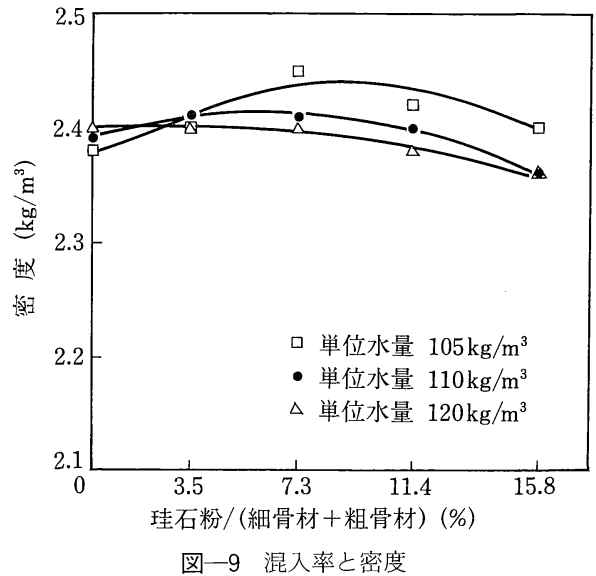

ら, 単位水量が $120 \mathrm{~kg} / \mathrm{m}^{3}$ では VC 值が小さく, 105 $\mathrm{kg} / \mathrm{m}^{3}$ では珪石粉の混入率 15.8 になると VC 值が急激 に大きくなっている. 図一8は混入率と圧縮強度（材齢 28 日）の関係である。この図から明らかなように，単 位水量が少ないほど圧縮強度が大きくなっている. 
表一8 珪石粉（石灰石粉，堆砂粉）を混入した場合の配合

\begin{tabular}{|c|c|c|c|c|c|c|c|c|}
\hline \multicolumn{4}{|c|}{ 混入率〔石粉/(細骨材＋粗骨材)〕（\%) } & 0.0 & 2.5 & 5.0 & 7.5 & 10.0 \\
\hline \multicolumn{2}{|c|}{ 粗骨材の最大寸法 } & & $(\mathrm{mm})$ & 80 & 80 & 80 & 80 & 80 \\
\hline \multicolumn{2}{|c|}{ 空 気 量 } & & $(\%)$ & 1.5 & 1.5 & 1.5 & 1.5 & 1.5 \\
\hline \multicolumn{2}{|c|}{ 水セメント比 } & $\mathrm{W} /(\mathrm{C}+\mathrm{F})$ & $(\%)$ & 87.5 & 87.5 & 87.5 & 87.5 & 87.5 \\
\hline \multicolumn{2}{|c|}{ フライアッシュ比 } & $\mathrm{F} /(\mathrm{C}+\mathrm{F})$ & $(\%)$ & 30 & 30 & 30 & 30 & 30 \\
\hline \multicolumn{2}{|c|}{ 細 骨材率 } & $\mathrm{S} / \mathrm{a}$ & $(\%)$ & 32 & 32 & 32 & 32 & 32 \\
\hline \multirow{5}{*}{$\begin{array}{l}\text { 単位重量 } \\
\left(\mathrm{kg} / \mathrm{m}^{3}\right)\end{array}$} & \multicolumn{2}{|l|}{ 水 } & W & 105 & 105 & 105 & 105 & 105 \\
\hline & \multicolumn{2}{|c|}{$\begin{array}{l}\text { フライアッシュ } \\
\text { セメント }\end{array}$} & $\mathrm{C}+\mathrm{F}$ & 120 & 120 & 120 & 120 & 120 \\
\hline & \multicolumn{2}{|l|}{ 細骨材 } & $\mathrm{S}$ & 703 & 686 & 670 & 655 & 640 \\
\hline & \multicolumn{2}{|l|}{ 粗骨材 } & G & 1,482 & 1,446 & 1,413 & 1,380 & 1,349 \\
\hline & \multicolumn{3}{|c|}{ 珪石粉（石灰石粉, 堆砂粉） } & 0 & 53 & 104 & 153 & 199 \\
\hline \multirow{2}{*}{ 配合特性 } & \multicolumn{3}{|l|}{$\alpha$} & 1.19 & 1.39 & 1.59 & 1.79 & 1.99 \\
\hline & \multicolumn{3}{|l|}{$\beta$} & 1.39 & 1.48 & 1.56 & 1.65 & 1.73 \\
\hline
\end{tabular}

また，珪石粉を $11.4 \%$ 混入した場合が，単位水量の 3 ケースとも最高の圧縮強度を示している.

次に，図一 9 は混入率と密度について示したものであ る.

この図から単位水量の変化による密度は，大きな差が ないが, 単位水量の少ない $105 \mathrm{~kg} / \mathrm{m}^{3}$ のケースの場合に 一部を除き大きな密度となっている.

以上の結果から考察すると，VC 值からは，20 秒程 度が最適であるので，単位水量は $105 \sim 110 \mathrm{~kg} / \mathrm{m}^{3}$ とな り, 強度からは, 単位水量が $105 \mathrm{~kg} / \mathrm{m}^{3}$ が良く, 密度も 単位水量 $105 \mathrm{~kg} / \mathrm{m}^{3}$ が大きくなっている，そこで，石粉 を混入した実験の単位水量は $105 \mathrm{~kg} / \mathrm{m}^{3}$ として実験を行 うこととした.

\section{6. 微粒分を変化させた場合（その1）の考察}

\section{（1）微粒分の混入率を変化させた場合の考察}

本実験は, 石灰石粉, 珪石粉, 堆砂粉の混入量を変化 させ，これに対して VC 值, 圧縮強度, 密度について の変化を検討したものである.また，フライアッシュを 珪石粉，堆砂粉で置換えを行った場合の VC 值，圧縮 強度, 密度の変化についても実験を行った。

次に, 珪石粉 (石灰石粉，堆砂粉）を混入した場合の 配合について表一8に示した．混入率は，珪石粉／(細 骨材十粗骨材）％で粗骨材は $G_{80}, G_{40}, G_{20}$ を 514 : 440：514の比率に配分した。この他, 混和剤としてポ ゾリス No. 8 を $0.3 \mathrm{~kg} / \mathrm{m}^{3}$ 用いた。なお，圧縮強度試験 の材齢は28 日とした.

以上の配合で実験した結果について述べる.

a) VC 值について

図-10 は石灰石粉, 珪石粉, 堆砂粉の変化亡 VC 值 の変化を示したものである.この図から明らかなように，

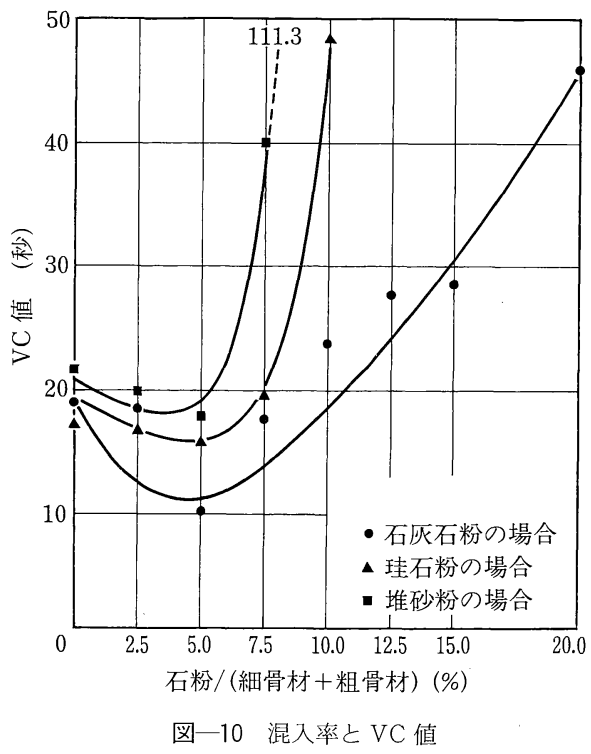

多少の変動はあるが一定の特性を示しており，この特性 について述べる. (1)石灰石粉, 珪石粉, 堆砂粉のすべて について $5.0 \%$ までの混入率であれば，VC 值が低下傾 向を示している。これ以上の混入率になると，急激に VC 值が増大している. (2)石粉混入率による VC 値の上 昇は, 堆砂粉, 珪石粉, 石灰石粉の順位となっている. (3)実際のダム施工ではVC 值が 20 秒程度でないと締固 めが困難であるから，石粉の混入率が堆砂粉では $5.0 \%$ 以下，珪石粉では $7.5 \%$ 以下，石灰石粉では $12.5 \%$ 以 下でないと施工が困難となるので，この混入率以下にす ベきである.

b）圧縮強度について

図一11 は石灰石粉，珪石粉，堆砂粉の変化と圧縮強 


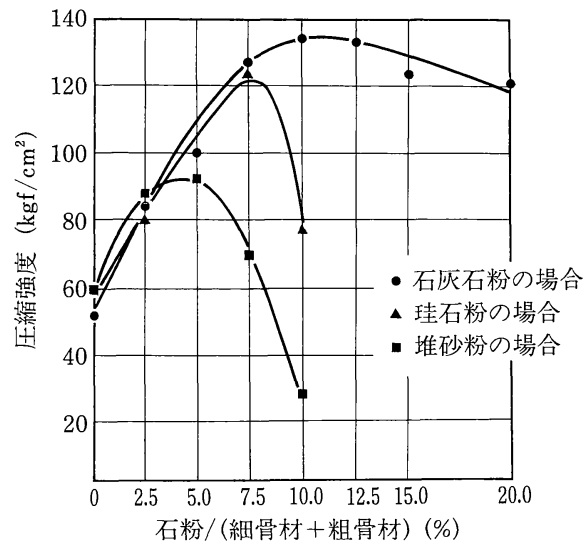

図一11 混入率之圧縮強度

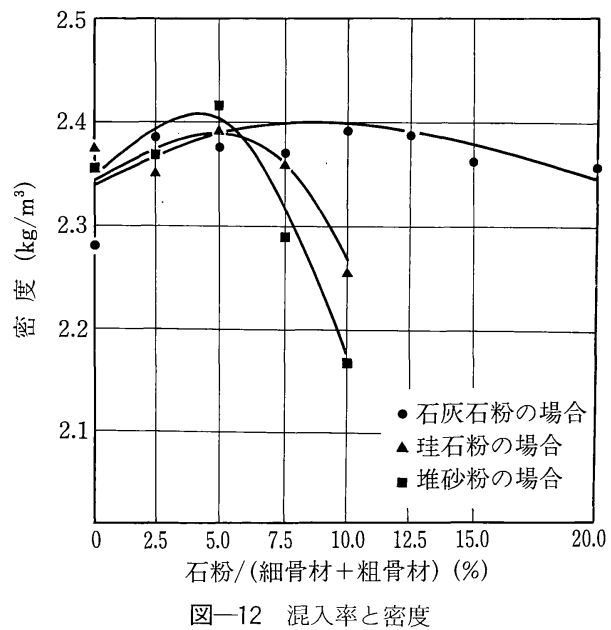

度の変化を示したものである.この図から，次のような 特性がある. (1)石灰石粉, 珪石粉, 堆砂粉の混入により 圧縮強度が増大している. 堆砂粉は混入率 $5.0 \%$, 珪石 粉は混入率 $7.5 \%$, 石灰石粉は混入率 $10 \%$ 以上になる と圧縮強度が低下している。(2)圧縮強度は堆砂粉が $5.0 \%$ 混入した場合に 1.5 倍, 珪石粉が $7.5 \%$ 混入した 場合に 2.0 倍, 石灰石粉が $10 \%$ 混入した場合に 2.2 倍 を示している.この強度の増加は予想以上に大きな値上 なったが，テストピース内のコンクリートのため横方向 の移動がないことによるものと考えられる．堤体上での 施工では RCD 用コンクリートが締固めにより横方向の 移動があるため, 本実験と同様の圧縮強度の増加はない 亡考えられる.しかし，石粉の混入により実際の施工で も相当に強度が増加するものと考えられる.

c) 密度について

図一12 は石灰石粉, 珪石粉, 堆砂粉の変化と密度の 変化について示したものである．この密度についても石 粉の変化により, 圧縮強度とある程度同様の傾向がある. この図から次のような特性が見られる. (1)堆砂粉, 珪石

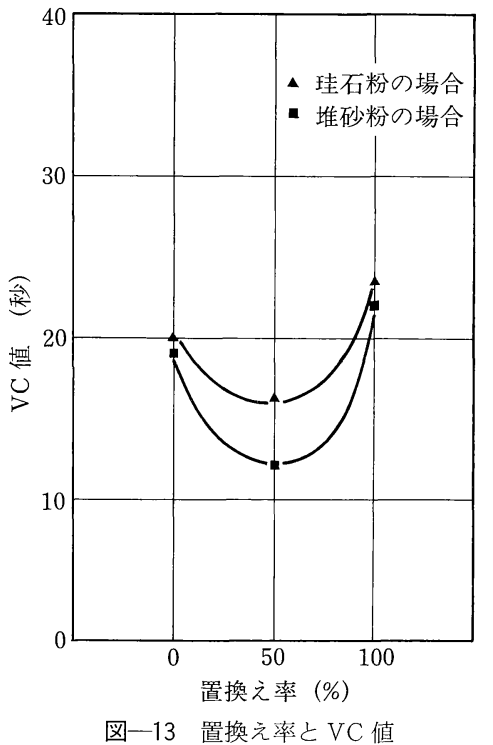

粉, 石灰石粉の混入率の増加により, それぞれの比重が 増大し, 堆砂粉, 珪石粉は $5.0 \%$, 石灰石粉は $10 \%$ でピー クを示し，これ以上の混入率の増加と共に密度は低下し ている.この原因は, 石粉の増加之共に密になり空陌が 減少し密度が増大するが，単位水量が一定であるので， 石粉量が適量を越えると, 急激にワーカビリティ一が悪 くなり, 締固めが十分に行われず空隙が多くなり, 密度 が小さくなるものと考えられる. (2)堆砂粉, 珪石粉, 石 灰石粉の混入によるそれぞれのピーク值は $2.4 \mathrm{~kg} / \mathrm{m}^{3}$ で 同程度であり，圧縮強度の石粉の種類によるピーク値の 変化より小さな値となっている.

（2）フライアッシュを石粉に置き換えた場合の考察 $\mathrm{RCD}$ 用コンクリートは, 一般にコンクリートの温度 上昇を小さくする目的でセメント量を少なくして，フラ イアッシュを $20 \sim 30 \%$ 混入し，強度の向上，施工性の 向上を図っている.このフライアッシュを珪石粉, 堆砂 粉で置換えを行った場合に如何なる特性を示すか実験を 行った.その結果を示すと次のようである.

a) VC值について

図一13 はフライアッシュを珪石粉, 堆砂粉に置き換 えた比率と VC 值の関係である.この図から，VC 值は 置換え率 $50 \%$ で低下し，100\% で上昇している．この ように置換え率が大きい場合にはVC值がわずかに大 きくなるものと考えられる。

b) 圧縮強度について

図一14 はフライアッシュを珪石粉, 堆砂粉に置き換 えた比率と圧縮強度材齢 28 日の関係である.この図か ら，圧縮強度は置換え率 $50 \%$ では同程度であり，100\% になるとわずかに低下している．このように石粉の置換 え率が大きくなると圧縮強度も低下するものと考えられ 
表一9 堆砂粉（石灰石粉，珪石粉）を混入した場合の配合

\begin{tabular}{|c|c|c|c|c|c|c|c|}
\hline \multicolumn{3}{|c|}{ 混入率〔石粉/(細骨材＋粗骨材)〕（\%) } & 0.0 & 2.5 & 5.0 & 7.5 & 10.0 \\
\hline \multicolumn{2}{|c|}{ 粗骨材の最大寸法 } & $(\mathrm{mm})$ & 80 & 80 & 80 & 80 & 80 \\
\hline \multicolumn{2}{|c|}{ 空 気 量 } & $(\%)$ & 1.5 & 1.5 & 1.5 & 1.5 & 1.5 \\
\hline \multicolumn{2}{|c|}{ 水セメント比 } & $(\%)$ & 80.8 & 80.8 & 80.8 & 80.8 & 80.8 \\
\hline \multicolumn{2}{|c|}{ フライアッシュ比 $\mathrm{F} /(\mathrm{C}+\mathrm{F})$} & $(\%)$ & 30 & 30 & 30 & 30 & 30 \\
\hline 細骨材率 & $\mathrm{S} / \mathrm{a}$ & $(\%)$ & 32 & 32 & 32 & 32 & 32 \\
\hline \multirow{5}{*}{$\begin{array}{l}\text { 単位重量 } \\
\left(\mathrm{kg} / \mathrm{m}^{3}\right)\end{array}$} & 水 & $\mathrm{W}$ & 105 & 105 & 105 & 105 & 105 \\
\hline & $\begin{array}{l}\text { フライアッシュ } \\
\text { セメント }\end{array}$ & $\mathrm{C}+\mathrm{F}$ & 130 & 130 & 130 & 130 & 130 \\
\hline & 細骨材 & S & 700 & 684 & 668 & 653 & 639 \\
\hline & 粗骨材 & G & 1,487 & 1,452 & 1,420 & 1,388 & 1,358 \\
\hline & 珪石粉（石灰石粉, & 砂粉） & 0 & 53 & 104 & 153 & 200 \\
\hline \multirow{2}{*}{ 配合特性 } & $\alpha$ & & 1.23 & 1.43 & 1.63 & 1.83 & 2.02 \\
\hline & $\beta$ & & 1.40 & 1.48 & 1.56 & 1.65 & 1.73 \\
\hline
\end{tabular}

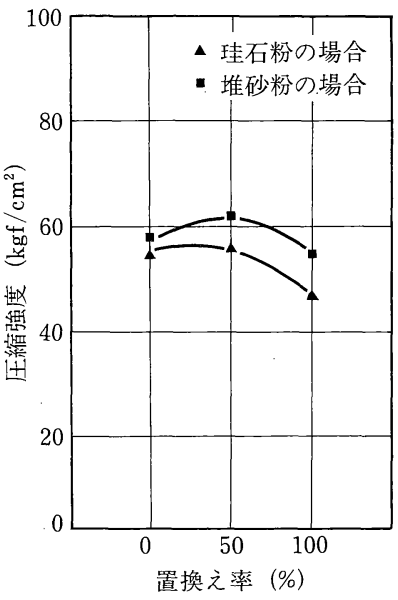

図一14 置換え率と圧縮強度

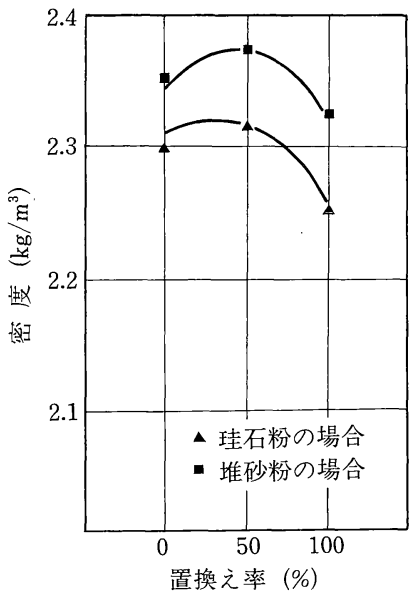

図一15 置換え率と密度
る.しかし，圧縮強度の低下は小さい。

c) 密度について

図一15 はフライアッシュを珪石粉，堆砂粉に置き換 えた比率と密度の関係である。この図から，密度は置換 え率 $50 \%$ では同程度であり，100\% になると低下して いる，密度も圧縮強度と同様に置換え率が大きくなると 低下するものと考えられる.

\section{7. 微粒分を変化させた場合（その 2$)$ の考察}

本実験は，結合材料 $(\mathrm{C}+\mathrm{F})$ が変化した場合，材齢 が長くなった時に, 石粉を混入した場合に如何なる特性 を示すか検討を行った. 前述の6. 微粒分を変化させた 場合（その1）と異なるのは，結合材料 C + F = 130 $\mathrm{kg} / \mathrm{m}^{3}$ ，材齢 91 日とした点である. また，（その 1 ）の 実験に近い実験を行うことにより信頼度の向上を図った ものである。

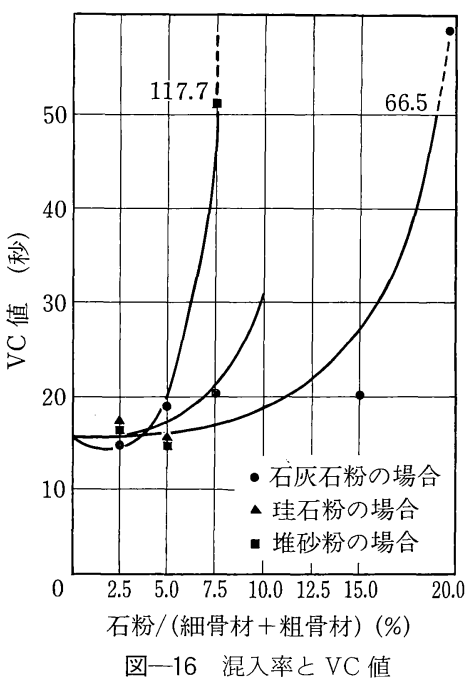

（1）微粒分の混入率を変化させた場合の考察

本実験も前述（その1） と同様に石灰石粉, 珪石粉, 堆砂粉の混入率を変化させ, これに対して VC 值, 圧 縮強度，密度についての変化を検討したものである。ま た, 堆砂粉 (石灰石粉, 珪石粉) を混入した場合の配合 について表一9に示した. 堆砂粉の混入率は, 堆砂粉／ (細骨材十粗骨材)％とした。粗骨材の配分，混和剤の 混入などは (その1）と同様とした。以上の配合で実験 した結果について述べる.

\section{a) VC 值について}

図一16 は, 石灰石粉, 珪石粉, 堆砂粉の混入率と $\mathrm{VC}$ 值の変化を示したものであり，(その 1 ) と同様の 特性を示している. その特性は，(1)石灰石粉, 珪石粉, 堆砂粉の混入率が $5 \%$ 程度であればVC 值は低下また は同程度となっている。(2)石粉混入率による VC 值の 
(材齢 28日)

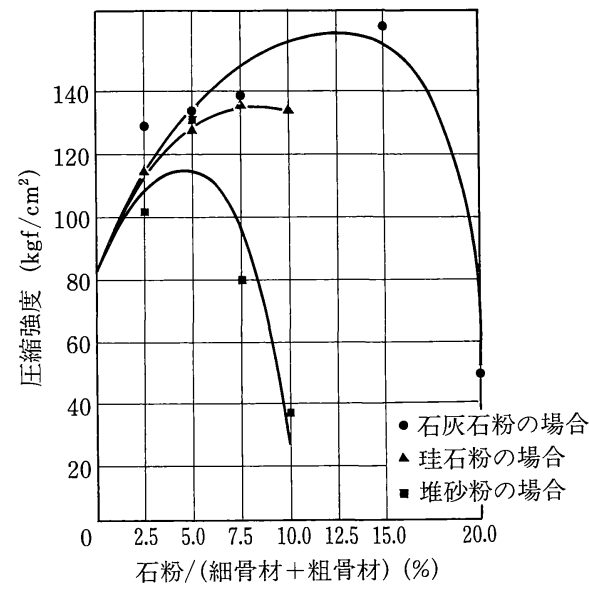

図-17 混入率と圧縮強度

（材齢 91日）

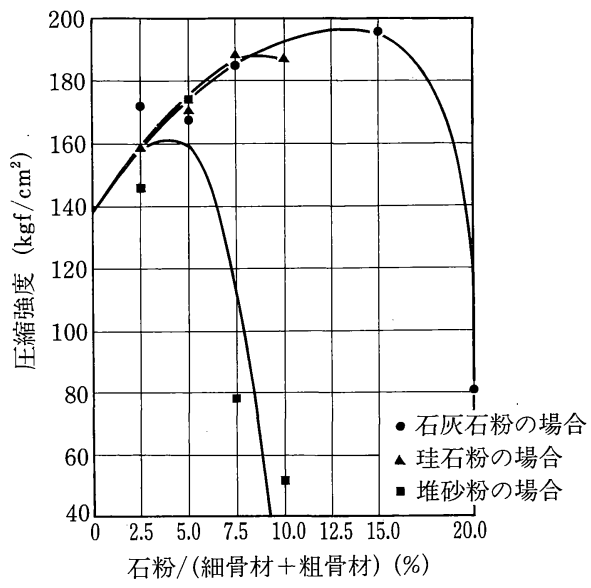

図一18 混入率と圧縮強度
上昇は, 堆砂粉, 珪石粉, 石灰石粉の順序となっている. (3) VC 值が 20 秒程度にするためには, 堆砂粉の混入量 $5.0 \%$ 以下，珪石粉 $7.5 \%$ 以下，石灰石粉 $12.5 \%$ 以下 にすべきである。

b) 圧縮強度について

図-17 は石灰石粉, 珪石粉, 堆砂粉の混入率と圧縮 強度の関係で, 材齢は 28 日, $\mathrm{C}+\mathrm{F}=130 \mathrm{~kg} / \mathrm{m}^{3}$ である. この図から，次のような特性がある. (1) C $+F=130$ $\mathrm{kg} / \mathrm{m}^{3}$ 亡したため, (その 1 ) の実験結果より圧縮強度 が大きくなっている. (2)石粉の混入により強度が増加し ている. 堆砂粉は $5.0 \%$, 珪石粉は $7.5 \%$, 石灰石粉は $12.5 \%$ で圧縮強度がピークを示し，これ以上の混入率 になると強度が低下している。 (3)圧縮強度の増加は堆砂 粉 1.4 倍, 珪石粉 1.7 倍, 石灰石粉 1.9 倍で, この順に 大きな値を示している. 特に石灰石粉は圧縮強度の増加 が大きく值となっている.

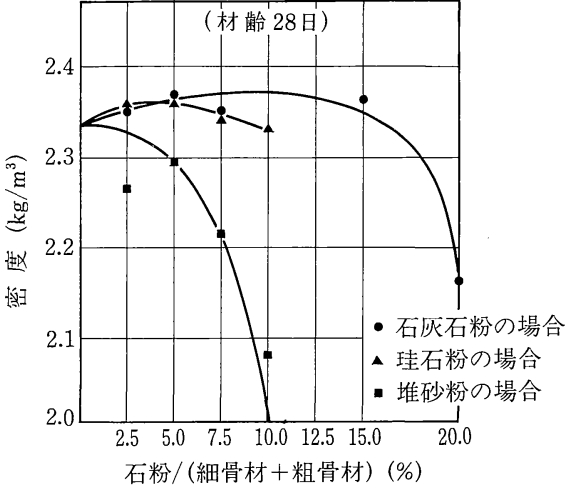

図一19 混入率と密度

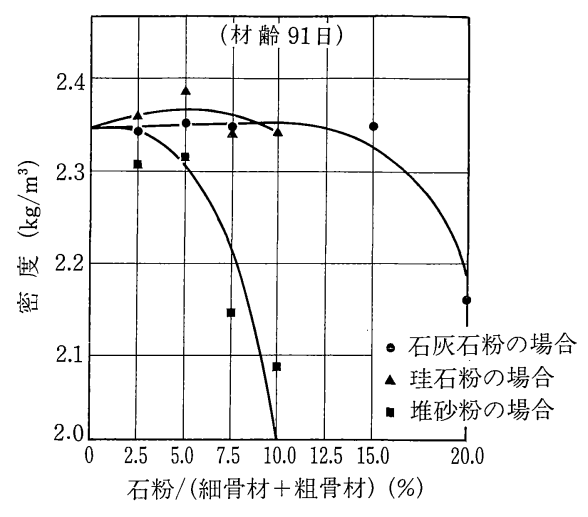

図一20 混入率亡密度

次に，材齢が 91 日の場合について石灰石粉，珪石粉， 堆砂粉の混入率と圧縮強度の関係について実験を行った 結果は図一18 となる。この結果から次のような特性が 見られる. (1)前述の材齢 28 日と比較して，ほぼ同様の 傾向を示している. (2)材齢 28 日と 91 日の圧縮強度の増 加率は, 混入しない場合 1.6 倍, 堆砂粉の場合 1.4 倍, 珪石粉の場合 1.4 倍, 石灰石粉の場合 1.2 倍亡なってい る.この結果からでは, 石粉の混入しない場合より, 混 入した場合には圧縮強度の増加率が小さくなっている. 特に石灰石粉を混入した場合には増加率が小さいが,, この原因は, 材齢 28 日の強度が大きな值を示していた からであると考えられる. (3)圧縮強度の最大值は, 混入 率が堆砂粉 $5.0 \%$, 珠石粉 $7.5 \%$, 石灰石粉 $12.5 \%$ の場 合で, 前述の材龄 28 日強度の場合と同様である.

c）密度について

図一19, 20 は, それぞれ材齢 28 日, 91 日のテストピー スについて, 石灰石粉, 珪石粉, 堆砂粉の変化亡密度の 関係を示したものである。これらの図から次のような特 性が見られる. (1)材齢が変っても密度が変化するもので なく, 材齢 28 日, 材齢 91 日の密度の関係は, 同様の傾 向を示している.このことから，材歯 28 日と材齢 91 日 のテストピースは同様に製作されていたものと考えられ 
る. (2)堆砂粉混入による密度は $2.5 \%, 5.0 \%$ の混入で も密度が低下している．この点が (その 1 ) の場合と異 なっているが, 珪石粉 $7.5 \%$, 石灰石粉 $12.5 \%$ 以下の 混入であれば, (その1) の傾向と同様であり,これ以 上の混入では密度が低下している.

\section{8. 結 論}

以上, 石灰石粉, 珪石粉, 堆砂粉の変化による RCD 用コンクリートの特性, フライアッシュを珪石粉, 堆砂 粉と置き換えた場合の RCD 用コンクリートの特性につ いて述べてきた.それらを要約すると以下のようである.

（1）堆砂粉 $5.0 \%$, 珪石粉 $7.5 \%$, 石灰石粉 $12.5 \%$ までの混入であれば，VC值は低下，または同程度の值 を示している.これ以上を混入すると急激に VC 值が 上昇している.このように適量の石粉の混入は RCD 用 コンクリートの締固めに効果的であると考えられる.

（2）結合材料 $120 \mathrm{~kg} / \mathrm{m}^{3}$ と $130 \mathrm{~kg} / \mathrm{m}^{3}$ に石粉を混入 した場合に, 最適石粉の混入有無に対する VC 值は, 結合材料の少ない $120 \mathrm{~kg} / \mathrm{m}^{3}$ の場合のほうが低下してい る.

（3）圧縮強度は, 石粉の混入により増加し, 石灰石 粉が最大で堆砂粉が最小であり, 堆砂粉 $5.0 \%$, 珪石粉 $7.5 \%$, 石灰石粉 $12.5 \%$ の混入率でピークを示している.

（4）結合材料 $120 \mathrm{~kg} / \mathrm{m}^{3}$ と $130 \mathrm{~kg} / \mathrm{m}^{3}$ に石粉を混入 した場合の圧縮強度の増加率は, 結合材料の少ない 120 $\mathrm{kg} / \mathrm{m}^{3}$ のほうが大きくなっている.

（5）材齢 28 日と 91 日の圧縮強度の増加率は, 石粉 を混入した場合のほうが，わずかに低下している.これ は石粉の混入により 28 日強度が大きくなっているから であると考えられる。

（6）密度は, 堆砂粉 $5.0 \%$, 珪石粉 $7.5 \%$, 石灰石 粉 $12.5 \%$ までの混入率であれば，わずかに上昇してい る.

（7）フライアッシュを珪石粉, 堆砂粉で置き換えた 場合は，両石粉ともに同様の傾向を示している. 石粉の 置換え率 $50 \%$ では, VC 値は低下傾向を示し, 圧縮強度, 密度は同程度を示している，置換え率 $100 \%$ では，VC
値が増大し，圧縮強度，密度が低下している。

以上のことから, 最適混入率は堆砂粉 $5.0 \%$, 珪石粉 $7.5 \%$, 石灰石粉 $12.5 \%$ 程度で, これらを混入した $\mathrm{RCD}$ 用コンクリートは, 施工性, 品質の向上が図れる ものと考えられる. また, 堆砂粉の利用は排砂対策にも 効果的である.

\section{参 考 文 献}

1）鈴木徳行・志水茂明：RCD 工法と RCC 工法との特性に ついて, 土木学会論文集, 第 403 号 $/ V I-10$, pp. 93 102, 1989.3.

2）鈴木徳行・白村 暁：コンクリートダムの合理化施工と 世界の動向, 月刊ダム日本, No. 575, pp. 57 71, 1992.

3）鈴木徳行 - 吳 偉剛：中国の RCD 工法について, ダム 技術, No.67, pp.3 15，1992. 4 .

4) International Symposium on RCC dams Water Power \& Dam Construction, pp.10 13,February 1992.

5) Department of Science and Technology, CEC:RCC DAMS IN CHINA pp.1 78, July 1991.

6) Chinese Society of Hydroelectric Engineering and ICOLD:International Symposium on Roller Compacted Concrete Dams, pp.1 526, November 1991.

7) M.R.H. Dunstan:A review of roller compacted concrete dams in the $1980 \mathrm{~s}$, Water Power \& Dam Construction, pp.43 45, May 1990.

8) M.R.H.Dunstan : Recent devcropments in roller compacted concrete dam construction, Water Power \& Dam Construction Handbook, pp.39 47, 1989.

9）鈴木徳行・飯坂武雄・白村 暁 : 微粒子の変化による $\mathrm{RCD}$ コンクリートの特性（その 2 ), 土木学会第 47 回年 次学術講演会講演概要集, pp. 588～589, 1992.

10）神山行男 ·吉岡保彦 - 米田正剛 - 小鳩平三：産業副産物 の RCD コンクリートへの有効利用に関する検討，第 7 回コンクリート工学年次講演会論文集, pp. 189 1 192, 1985.

11）建設省玉川ダム工事事務所：細骨材の粒度が品質に及ぼ す影響についての試験，玉川ダムの RCD 工法，pp. 3028 ～3030, 1990 年 3 月.

12）鈴木徳行・飯坂武雄・平間昭信：微粒分の変化に上る $\mathrm{RCD}$ コンクリートの特性, 土木学会第 46 回年次学術講 演会講演概要集, pp. 548 549, 1991 年 9 月.

(1993.6.14 受付)

\section{EFFECTS OF CHANGING THE MIXING RATIO OF FINE POWDERS ON CHARACTERISTICS OF RCD CONCRETE}

Satoru SHIRAMURA and Noriyuki SUZUKI

In this study, we investigated the characteristics of the RCD concrete such as The VC value, compressive strength and density in varying the mixing ratio of lime stone powder, silica stone powder, and deposited silt powder. We obtained the most efficient mixing ratio of each stone powder, in which the $\mathrm{VC}$ value was proper, and the compressive strength and density was highest. 